\title{
Greenhouses - urban biodiversity hotspot of alien Oribatida (Acari) species
}

\author{
Mateusz Oszust, Ziemowit OlsZANOwsKi, Marta PrZYMUSZAŁA and Aleksandra JAGIEŁŁO \\ Department of Animal Taxonomy and Ecology, Adam Mickiewicz University in Poznań Umultowska 89, \\ 61-614 Poznań, Poland; e-mail: matosz@st.amu.edu.pl
}

\begin{abstract}
Palm houses and other greenhouses, due to maintaining constant temperature and humidity, allow the cultivation in Europe of plants from different parts of the world, even from tropical regions. However, sometimes they are also a habitat for alien species of spiders, mites, insect, etc. These animals have been introduced accidentally with contaminated plants, seeds, seedlings, soil and thanks to stable conditions maintained in greenhouses, they may colonize these places. Example of arthropods, of which even tropical species occur in several greenhouses, are oribatid mites minute saprophagous arachnids that mostly inhabit soil. In Europe they are represented by about 2,000 species, while worldwide - over 10,000 taxa were described. The aim of this research was to investigate the selected greenhouses for the biodiversity of oribatid mites and the presence of non-native species. In total, 49 taxa were recorded, including 23 alien species (for example, a Neotropical taxon Galumna hamifer, or Oriental Suctobelbella parallelodentata). These results confirm that greenhouses are the places of occurrence of many alien oribatid species. The obtained results may be used in future research on the biology of poorly known tropical mites.
\end{abstract}

Key words: Palm house, new records, accidental introduction, oribatid mites, moss mites

\section{INTRODUCTION}

According to the EASIN database (2020), about 5,012 non-native animal species occur in Europe and most likely, with the progress of climate change, increased global trade, tourism, agriculture, horticulture, this number will increase (Seebens et al. 2017). However, this list is not complete, because some of them could hide in such unexpected places as e.g. palm houses or other greenhouses with exotic plants, where different non-native invertebrate species (even also from tropical regions) can be found. These animals have been introduced accidentally with contaminated plants, seeds, seedlings, soil, etc. Due to stable temperature and moisture conditions maintained in greenhouses, as well as the absence of natural predators, alien spiders, mites, or insects may colonize greenhouses.

In previous works, researchers showed the presence of exotic spiders, insects and other invertebrates in such places (Teodorescu \& Matei 2010, Kolicka et al. 2015). Thanks to mentioned the features, greenhouses may be considered as "tropical islands" for alien invertebrates (Kolicka et al. 2015).

Greenhouses can also be a useful source of knowledge about tropical invertebrates. For example, the knowledge of alien taxa distribution within greenhouses may be helpful in collecting individuals to conduct research on their biology or in preparing DNA barcode sequences (Scott-Brown et al. 2018, Zawierucha et al. 2013).

Some alien oribatid species were recorded in the previous studies (Aoki 1992, Skubała et al. 2001, Niedbała 2010, 2014, 2018, Bochniak 2015, Kolicka et al. 2016). That is why we wanted to study the presence of alien species in other several greenhouses. The purpose of this work is to present new records of alien Oribatida that were found in four European greenhouses. 


\section{Material AND MethodS}

The research was carried in four places: Berlin-Dahlem Botanical Garden and Botanical Museum (BGBM), Fata Morgana Greenhouse in Prague (FMG), Ecology Center, A.S. Pushkin Brest State University (EC) and Central Botanical Garden of the National Academy of Sciences of Belarus in Minsk (CBG).

In BGBM and FMG, 30 soil samples were collected from under plants, while in CBG and EC - 15 and 20, respectively. However, sample collecting in FMG was repeated by another group of researchers (with the same number of samples), because the list with sampling sites in the greenhouse was lost due to a computer error. Results of the first sampling are presented in Table 1 under the heading FMGI, while those of the second sampling - under FMGII. After extraction with a modified Tullgren apparatus, specimens were preserved in $85 \%$ ethanol and identified to the species level. Mites from the morphotype Ptyctima were not considered in this article, because the results were previously presented in another work (Niedbała 2018). Species names and distribution were updated according to Subias 2019.

\section{SAMPLES LIST}

\section{Berlin-Dahlem Botanical Garden and Botanical Museum (BGBM)}

Collected on 21 February 2014 by A. Łukasiewicz:

o Main pavilion:

- Under Costus dubius (Afzel.) K. Schum. 1904: Ramusella insculpta (Paoli, 1908) (8)

- America and Africa section, under Ctenanthe sp. Eichler, 1884: Ramusella insculpta (6), Suctobelba cornigera Shtanchaeva \& Subías, 2009 (2), Tectocepheus velatus (Michael 1880) (1)

- South America section, under Chamaedorea seifrizii Burret, 1938 from the Caribbean: Scheloribates pallidulus (Koch, 1841) (1)

o Pavilion of orchids:

- Under Pleurothallis sp. R.Br. 1813: Ramusella insculpta (2), Berlesezetes ornatissimus (Berlese, 1913) (1), Scheloribates pallidulus (8), Acrogalumna longipluma (Berlese, 1904) (6)

o Pavilion L under log: Tectocepheus velatus (36)

o Pavilion of tropical plants:

- Under Neoregelia sp. L. B. Smith, 1934: Ramusella insculpta (5), Oppiella nova (Oudemans, 1902) (6), Suctobelbella nasalis (Forsslund, 1941) (4), Tectocepheus velatus (4), Berlesezetes ornatissimus (2)

- The plants from South America, under Heliconia sp. L., 1771: Tectocepheus velatus (4), Protoribates dentatus (Berlese, 1883) (1)

- Under the plants from Africa: Ramusella insculpta (10), Tectocepheus velatus (18)

Fata Morgana Greenhouse in Prague (FMGI) (non-native species are present in Table 2)

Collected on 08 June 2015, by S. Chmielewski and M. Draga:

Epilohmannia cylindrica (Berlese, 1904) (39), Hemileius sp. Berlese, 1916 (150), Scutovertex minutus (Koch, 1836) (33), Autogneta longilamellata (Michael, 1885) (1), Tectocepheus sp. Berlese, 1896 (6), Suctobelbella palustris (Forsslund, 1951) (1), Carabodes labyrinthicus (Micheal, 1879) (1), Acrogalumna longipluma (5), Camisia spinifer (Koch, 1836) (1), Malaconothrus sp. Berlese, 1904 (22), Oppiella nova (1), Ramusella insculpta (9), Kuklosuctobelba claviseta (Hammer, 1961) (2)

\section{Fata Morgana Greenhouse in Prague (FMGII)}

Collected on 11 July 2018 by M. Oszust, J. Wysocka and D. Fajfer: 
o Succulent, savannah, semi-desert pavilion:

- Under Pachypodium rutenbergianum Vatke 1885: Protoribates dentatus (1), Pergalumna bryani (Jacot, 1934) (1)

o Tropical rainforest pavilion:

- Under Molineria capitulata (Lour.) Herb., 1837: Protoribates dentatus (1)

- Under Lantana sp. L., 1753: Kuklosuctobelba perbella Chinone, 2003 (1)

- Under Piper ornatum N. E. Br., 1854: Epilohmannia cylindrica (1), Nothrus anauniensis Canestrini \& Fanzago, 1877 (1)

- Under Alpinia zerumbet (Pers.) B. L. Burtt \& R. M. Sm., 1972: Arcoppia cronus winkleri (Hammer, 1968) (3), Multioppia sp. Hammer, 1961 (7), Berlesezetes ornatissimus (1)

- Under Didymochlaena truncatula (Sw.) J. Sm., 1842: Suctobelbella parallelodentata (1)

- Under Gymnostoma deplancheanum (Miq.) L. A. S. Johnson, 1982: Nothrus pratensis Sellnick, 1928 (1), Tectocepheus sp. (1)

- Under Calyptrocalyx polyphyllus Becc., 1923: Galumna hamifer Mahunka, 1985 (1)

- Under Philodendron mamei Andre, 1883: Tectocepheus sp. (1), Rostrozetes foveolatus (Berlese, 1908) (1), Protoribates dentatus (1)

- Under Verschaffeltia splendida H. A. Wendl, 1865.: Tectocepheus sp. (1), Galumna hamifer (2), Achipteria nitens (Nicolet, 1855) (1)

- Under Scindapsus pictus Hassk., 1842: Protoribates dentatus (1), Oppiella nova (1)

- Under Cyathea incisoserrata Copeland, 1911: Epilohmannia cylindrica (3)

o Mountain pavilion:

- Under Monochaetum vulcanicum Cogn., 1891: Kuklosuctobelba perbella (1), Quadroppia hammerae Mínguez, Ruiz \& Subías, 1985 (1)

- Under Streptocarpus wendlandii Spreng.: Kuklosuctobelba perbella (5)

- Under Plectranthus bipinnatus Paton, 2003: Galumna hamifer (7), Rostrozetes foveolatus (1)

- Under Agathis philippinensis Warb., 1900: Rostrozetes foveolatus (1)

- Under Clivia gardeni Hooker., 1856: Rostrozetes foveolatus (1), Acrogalumna longipluma (2), Achipteria nitens (7)

\section{Ecology Center A.S. Pushkin Brest State University (EC)}

Collected on 11 April 2017 by M. Oszust and M. Zmudziński

o Tropical pavilion:

- Under Spathiphyllum wallisii Regel, 1877 from America: Epilohmannia cylindrica (1), Kuklosuctobelba perbella (1), Protoribates sp. (1)

- Under Asplenium bulbiferum G. Forst, 1786 from New Zealand: Protoribates dentatus (2), Kuklosuctobelba perbella (3), Protoribates Berlese, 1908 sp. (5)

- Under Rhododendron obtusum Planch, 1854 from Japan: Ramusella insculpta (1), Protoribates dentatus (2), Epilohmannia cylindrica (1)

- Under Begonia bowerae Ziesenh., 1950 from Mexico: Epilohmannia cylindrica (1), Suctobelbella penicillata (Balogh \& Mahunka, 1966) (1), Kuklosuctobelba perbella (2)

- Under Billbergia saundersii hort. Ex Dombrain, 1871 from Central America: Ramusella insculpta (1), Suctobelbella penicillata (1)

- Under Dichorisandra hexandra (Aubl.) Standl., 1925: Pseudoamerioppia paraguayensis (Balogh \& Mahunka, 1981) (2), Protoribates sp. (1)

- Under Tradescantia spathacea Sw., 1788 From the Antilles: Protoribates dentatus (1),

- Under wood log: Protoribates dentatus (2), Berlesezetes ornatissimus (1), Epilohmannia cylindrica (1) 
o Subtropical pavilion

- Under Cycas sp. L., 1753 from eastern Asia: Kuklosuctobelba perbella (1)

- Under Asparagus densiflorus (Kunth) Jessop, 1966 from Spain: Protoribates dentatus (1), Kuklosuctobelba perbella (1), Suctobelbella perforata (Strenzke, 1950) (1)

- Under Laurus nobilis L., 1753 from Mediterranean Sea: Protoribates dentatus (1)

- Under Neoregelia ampullacea (E. Morren) L. B. Smith, 1934 from Brazil: Epilohmannia cylindrica (2), Suctobelbella penicillata (1)

\section{o Balcony}

- Under Trachycarpus fortune (Hook) H. Wendl., 1861 from Japan and Oplismenus hirtellus (L.) P. Beauv., 1812 from the USA: Hypochthonius rufulus Koch, 1835 (3)

- Under Camelia japonica L., 1753 from Japan: Protoribates dentatus (1),

- Under Citrus paradisi Macfad, 1837 from Asia: Protoribates dentatus (17)

\section{Central Botanical Garden of the National Academy of Sciences of Belarus in Minsk (CBG)}

Collected on 12 April 2017 by M. Oszust and M. Zmudziński:

- Under stones and Auracaria araucana (Molina) K. Koch, 1873: Protoribates dentatus (1)

- Under Cyrtomium falcatum (L.f.) Presl, 1836: Acrogalumna longipluma (1), Hypochthonius rufulus (1), Epilohmannia cylindrica (11)

- Under the clamps of Ficus sp. L., 1753: Protoribates dentatus (1), Berlesezetes ornatissimus (1), Ramusella insculpta (3)

- Under Callisia repens (Jacq.) L., 1762: Protoribates dentatus (3), Acrogalumna longipluma (2), Pseudoamerioppia paraguayensis (1)

- Under Schefflera arboricola (Hayata) Merr., 1916: Protoribates dentatus (2)

- Under Viburnum suspensum Lindl., 1853: Acrogalumna longipluma (1)

- Under Nephrolepis exaltata (L.) Schott, 1834: Protoribates dentatus (1), Acrogalumna longipluma (3), Kuklosuctobelba perbella (1)

\section{RESULTS}

In total, 821 individuals and 49 species of oribatid mites were recorded. The number of individuals and species from each greenhouse were presented in Table 1. The mites with the following natural distribution prevailed: Cosmopolitan (11 species), Neotropical (12 sp.) and Palearctic (11 sp.). A slightly lower number of species was associated with Holarctic (7 sp.) and Oriental (5 sp.) realms. All tropical regions (Pantropical distribution) were represented by 4 taxa. Only 2 mites were characteristic for Australian and one for Ethiopian Zone. Nevertheless, many species were associated with more than one zoogeographic realm; thus a reliable determination of their origin is impossible.

Table 1. Number of individuals and species of oribatid mites from each greenhouse

\begin{tabular}{|c|c|c|c|c|c|}
\hline & BGBM & FMGI & FMGII & EC & CBG \\
\hline Number of individuals & 152 & 481 & 93 & 60 & 35 \\
\hline Number of species & 11 & 24 & 21 & 10 & 8 \\
\hline Number of alien species & 4 & 12 & 9 & 5 & 4 \\
\hline
\end{tabular}

Non-native species comprised 23 taxa, i.e., 46.94\% of all recorded species (Table 2). Most of them occur in the Neotropical region, but many are also typical for Palearctic (mostly south part and Japan). The richest in taxa was the superfamily Trizetoidea ( 7 species). Among the recorded alien mites, many belong also to Oripodoidea ( 5 species) and Oppioidea (4 species). 
Table 2. List of non-native species of oribatid mites found in all greenhouses. Data of distribution after Subias 2019

\begin{tabular}{|c|c|c|c|c|c|c|c|c|}
\hline Superfamily & Species & Distribution & BGBM & $\mathrm{CBG}$ & $\mathrm{EC}$ & FMGI & FMGII & Total \\
\hline Cosmochthonioidea & $\begin{array}{l}\text { Cosmochthonius } \\
\text { reticulatus Grandjean, } \\
1947\end{array}$ & $\begin{array}{l}\text { South Palearctic, } \\
\text { Oriental and } \\
\text { Neotropical }\end{array}$ & & & & 2 & & 2 \\
\hline Lohmannioidea & $\begin{array}{l}\text { Lohmannia jornoti } \\
\text { Mahunka, } 1985\end{array}$ & Neotropical & & & & 5 & & 5 \\
\hline Crotonioidea & $\begin{array}{l}\text { Allonothrus russeolus } \\
\text { Wallwork, } 1960\end{array}$ & $\begin{array}{l}\text { Ghana, Oriental, } \\
\text { Neotropical and } \\
\text { Japan }\end{array}$ & & & & 17 & & 17 \\
\hline Microzetoidea & $\begin{array}{l}\text { Berlesezetes ornatissimus } \\
\text { (Berlese, 1913) }\end{array}$ & $\begin{array}{l}\text { Pantropical and } \\
\text { subtropical }\end{array}$ & 6 & 1 & 1 & & 2 & 10 \\
\hline Oppioidea & $\begin{array}{l}\text { Arcoppia cronus winkleri } \\
\text { (Hammer, 1968) }\end{array}$ & Australian & & & & & 4 & 4 \\
\hline Oppioidea & $\begin{array}{l}\text { Aeroppia nasalis } \\
\text { Mahunka, } 1984\end{array}$ & $\begin{array}{l}\text { Neotropical } \\
\text { (Paraguay and Brazil) }\end{array}$ & & & & 11 & & 11 \\
\hline Oppioidea & $\begin{array}{l}\text { Aeroppia sp. Hammer, } \\
1961\end{array}$ & $\begin{array}{l}\text { Neotropical,Oriental } \\
\text { and Holarctic }\end{array}$ & & & & 21 & & 21 \\
\hline Oppioidea & $\begin{array}{l}\text { Pseudoamerioppia } \\
\text { paraguayensis (Balogh \& } \\
\text { Mahunka, 1981) }\end{array}$ & $\begin{array}{l}\text { Neotropical and } \\
\text { Canarias }\end{array}$ & & 1 & 2 & & & 3 \\
\hline Trizetoidea & $\begin{array}{l}\text { Suctobelba cornigera } \\
\text { Shtanchaeva \& Subías, } \\
2009\end{array}$ & Caucasus & 2 & & & & & 2 \\
\hline Trizetoidea & $\begin{array}{l}\text { Suctobelbella } \\
\text { kaliurangensis Hammer, } \\
1979\end{array}$ & Oriental (Indonesia) & & 3 & & & & 3 \\
\hline Trizetoidea & $\begin{array}{l}\text { Suctobelbella nasalis } \\
\text { (Forsslund, 1941) }\end{array}$ & $\begin{array}{l}\text { Palearctic and New } \\
\text { Zealand }\end{array}$ & 5 & & & & & 5 \\
\hline Trizetoidea & $\begin{array}{l}\text { Suctobelbella } \\
\text { parallelodentata, Hammer, } \\
1979\end{array}$ & Oriental & & & & & 1 & 1 \\
\hline Trizetoidea & $\begin{array}{l}\text { Suctobelbella penicillata } \\
\text { (Balogh \& Mahunka, } \\
\text { 1966) }\end{array}$ & $\begin{array}{l}\text { Ethiopian and } \\
\text { Neotropical }\end{array}$ & & & 3 & & 1 & 4 \\
\hline Trizetoidea & $\begin{array}{l}\text { Kuklosuctobelba claviseta } \\
\text { (Hammer, 1961) }\end{array}$ & $\begin{array}{l}\text { Peru, Hawai, } \\
\text { Madagascar and } \\
\text { Japan }\end{array}$ & & & & 2 & & 2 \\
\hline Trizetoidea & $\begin{array}{l}\text { Kuklosuctobelba perbella } \\
\text { Chinone, } 2003\end{array}$ & Japan & & & 8 & & 11 & 19 \\
\hline Ceratozetoidea & $\begin{array}{l}\text { Lamellobates misella } \\
\text { (Berlese, 1910) }\end{array}$ & $\begin{array}{l}\text { Pantropical and } \\
\text { South Palearctic }\end{array}$ & & & & 59 & & 59 \\
\hline Galumnoidea & $\begin{array}{l}\text { Galumna hamifer } \\
\text { Mahunka, } 1985\end{array}$ & Neotropical & & & & 58 & 23 & 81 \\
\hline Galumnoidea & $\begin{array}{l}\text { Pergalumna bryani (Jacot, } \\
\text { 1934) }\end{array}$ & $\begin{array}{l}\text { Pacific Islands and } \\
\text { Neotropical }\end{array}$ & & & & & 1 & 1 \\
\hline Oripodoidea & $\begin{array}{l}\text { Benoibates sp. Balogh, } \\
1958\end{array}$ & $\begin{array}{l}\text { Pantropical (without } \\
\text { Oriental) }\end{array}$ & & & & 4 & & 4 \\
\hline Oripodoidea & $\begin{array}{l}\text { Protoribates dentatus } \\
\text { (Berlese, 1883) }\end{array}$ & $\begin{array}{l}\text { Holarctic and } \\
\text { Oriental }\end{array}$ & 10 & 9 & 27 & & 10 & 56 \\
\hline Oripodoidea & $\begin{array}{l}\text { Peloribates genavensium } \\
\text { Mahunka, } 1983\end{array}$ & Mexico & & & & 4 & & 4 \\
\hline Oripodoidea & $\begin{array}{l}\text { Rostrozetes foveolatus } \\
\text { (Berlese, 1908) }\end{array}$ & $\begin{array}{l}\text { Pantropical and } \\
\text { Subtropical }\end{array}$ & & & & 10 & 13 & 23 \\
\hline Oripodoidea & $\begin{array}{l}\text { Mochlozetes penetrabilis } \\
\text { Grandjean, } 1930\end{array}$ & $\begin{array}{l}\text { Neotropical and } \\
\text { Japan }\end{array}$ & & & & 22 & & 22 \\
\hline Total & & & 23 & 14 & 41 & 215 & 66 & 359 \\
\hline
\end{tabular}




\section{DISCUSSION}

Obtained results show that greenhouses are habitats for both native and alien mites. The recorded species are associated with different zoogeographic realms, mostly with Neotropics and Palearctic. Several taxa, such as Rostrozetes foveolatus, are very rare in the world fauna (Skubała et al. 2001), while other are restricted to single areas, for example: Suctobelba cornigera to Caucasus and Kuklosuctobelba perbella to Japan (Subias 2019). However, the occurrence of a given taxon in Europe does not always mean that individuals from the recorded species came from local populations. Many species among the observed mites have cosmopolitan distribution, for example, Acrogalumna longipluma that was found in all greenhouses investigated by the authors as well as by Kolicka et al. (2016) on Bromeliaceae. Apart from Holarctic, these mites occur also in New Zealand and in Oriental and Ethiopian regions (Subias 2019). They live in different habitats, such as forest floor, dead wood, ants' nests, lichens or mosses (Seniczak 2012, Skubała \& Marzec 2013). Additionally, Hammer (1969) found A. longipluma among specimens of Primula sp. L., 1753 imported from England. Therefore, it is possible that these individuals came from alien populations. Several species occur in the majority of investigated greenhouses, e.g. Berlesezetes ornatissimus (Fig. 1). This might be caused, for instance, by plant exchange between greenhouses or specific conditions that favor certain taxa.

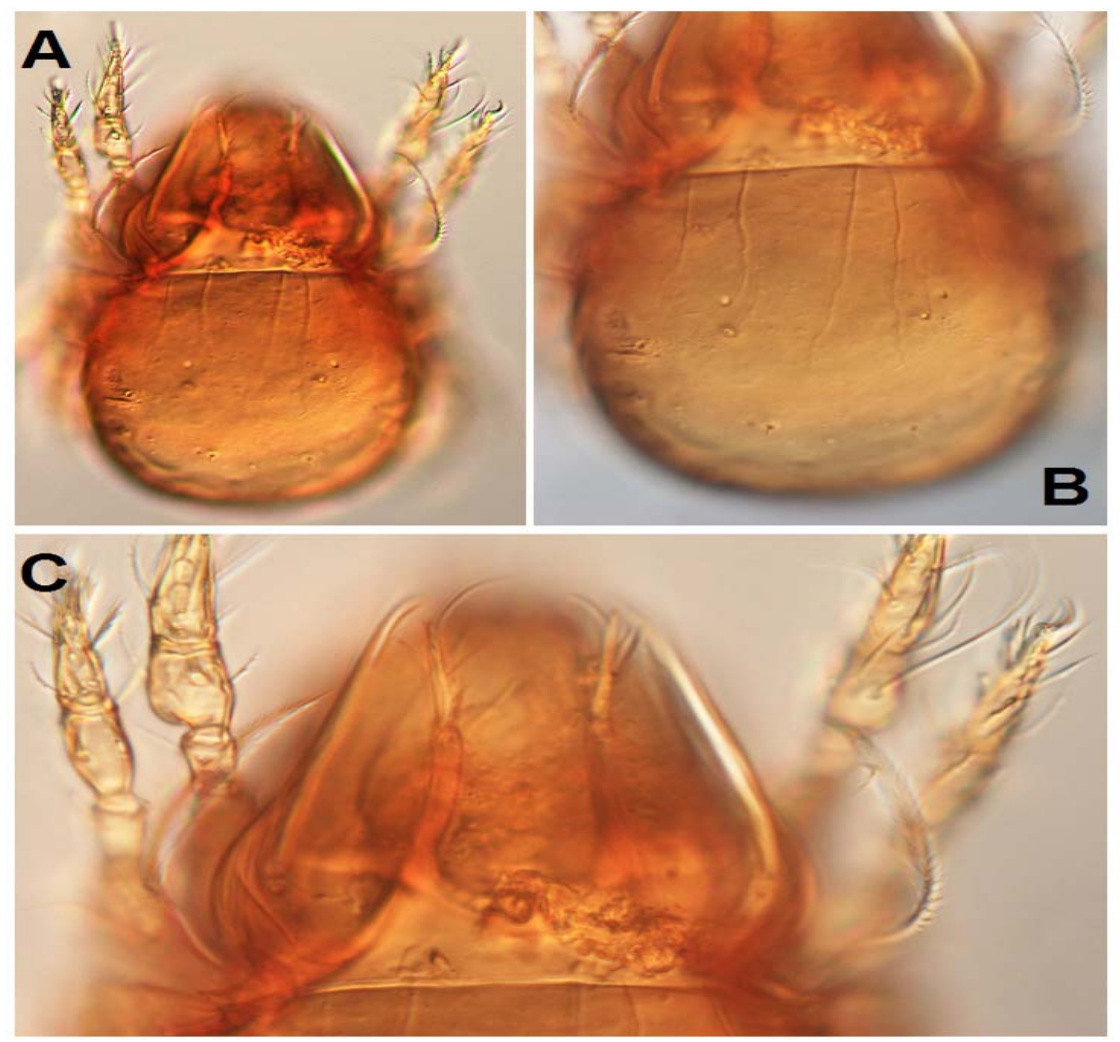

Fig. 1. Berlesezetes ornatissimus (Berlese, 1913) specimen from The Berlin-Dahlem Botanical Garden. Photos by M. Kolicka. A - dorsal view; B - notogaster (dorsal view); C-prodorsum (dorsal view). 
Despite constant humidity and temperature, a greenhouse might not to be a good habitat to live for some species due to, among others, agrotechnical measures: fertilization of soil, removal of dead plant material (Skubała et al. 2001), using pesticides, etc. It is difficult to estimate how many species were imported to greenhouses and which one could colonize such environments. However, Hammer (1969) during research on material from Plant Quarantine Station in the U.S.A, found 165 oribatid species (including alien), which indicates that mites may have a big potential for dispersal during plant transport.

The place richest in oribatid mites taxa was Fata Morgana Greenhouse in Prague, where probably not all alien species were found. The reliable identification of several species was problematic, for example, Benoibates sp. is very similar to B. excavatus (Woolley 1961); however, the shape of sensillus and arrangement of notogastral setae raise doubts. Regretfully, location of holotype is unknown.

One of the most common species in all investigated greenhouses and in the work of Bochniak 2015 is Protoribates dentatus. P. dentatus was treated as an alien species despite its Holarctic distribution, because this taxon has not been previously recorded in the Czech Republic (Miko 2016). In Europe (excluding greenhouses), P. dentatus was found only in Italy, Slovakia and Germany (Weigmann 2006). This mite is xylophagus, its juveniles bore channels in the wood (Seniczak et al. 2018); therefore, it is possible that it was introduced with trees, wood or timber humus. Adults also occur in soil and Wissuwa et al. (2013) noticed their preference for substratum rich in organic carbon, thus, a high abundance of $P$. dentatus may be associated with plant fertilization.

Other Oribatida common to all greenhouses are mites from genus Epilohmannia Berlese, 1910. Several species, such as E. cylindrica or E. minima, are considered as xerophilic (Weigmann 2006); thus stable warm temperature in a greenhouse may favour their survival. Additionally, according to Norton \& Palmer (1991), some Epilohmannia species could be parthenogenetic.

The diversity of alien species in greenhouses have not been fully investigated yet. Skubała et al. (2001) during their research in Gliwice and Sosnowiec recorded 37 species and only 7 were non-native. Niedbała (2010) and Bochniak 2015 found 25 taxa (8 non-native) in the Poznań Palm House. Additionally, Niedbała $(2014,2018)$ in material from the Palm houses in Łódź, BGBM, CBG, FMGI and EC found 8 alien mites from the morphotype Ptyctima. However, the majority of previous studies focused on soil fauna and neglected mites inhabiting plants. Only Kolicka et al. (2016) noted 5 species (all cosmopolitan or semi-cosmopolitan) from Bromeliaceae and Aoki (1992) found 4 orchid taxa (3 alien) from of the genus Vanda Jones ex R. Br. 1820 in Japan. However, sizes of mites make collecting of individuals without damaging plants very difficult.

Another problem of all studies is that species identification is based solely on morphological features. Several works provide evidence on the presence of cryptic species among Oribatida, so there is a risk of incorrect identification of taxa (Schäffer et al. 2019). On the other hand, in the BOLD (2020) database, only about 610 among 10,000 species of Sarcoptiformes (group comprising Oribatida and Astigmata) have barcode sequences, so in most cases, molecular identification is impossible.

Greenhouses could also serve as a shelter for invasive animals or plants because some brought taxa might escape and become respectively pests or weeds as well as a threat to local biodiversity. One of the factors that prevent colonisation of European areas by alien animals and plants species from warmer regions is the presence of colder periods (Wang et al. 2015). For instance, sweetpotato whitefly, Bemisia tabaci (Gennadius 1889), is a thermophilic pest that was accidentally introduced to several countries and feed on different species of crop plants. However, this species is sensitive to low temperatures, and it is believed to be able to survive adverse conditions due to wintering in greenhouses (Lin et al. 2007). 
Because of global warming, winters have been becoming milder thus in the future some species might be capable of establishing stable populations outside greenhouses (Zangl et al. 2019). On the other hand, the expansion of alien species can also be limited not only by low environmental temperatures but also by their dispersal ability and various abiotic and biotic factors such as competition, natural disturbance, availability of water or food (Williamson \& Harrison 2002, Sexton et al. 2009).

Oribatida thanks to their minute sizes can spread over a further distance with the wind, with the participation of other animals (e.g. insect) or during transporting of plants, as well as many species are parthenogenetic and generalist in their diet, so several greenhouse mites might be capable of colonising natural environment (Hammer 1969, Norton 1980, Domes et al. 2007, Lehmitz et al. 2011, Magilton et al. 2019). This hypothesis requires verification, therefore, further research should focus not only on greenhouses but also on areas around them, e.g. parks, lawns, gardens, etc. to get to know which alien species are capable of escaping and surviving in outside conditions, at least during the summer season. To summarise, greenhouses and their fauna might be also model to research on effects of global warming (Kolicka et al. 2015).

The majority of the described species have not been sufficiently investigated (Beore 2010) and this trend occurs also in many oribatid mite groups. For example, according to BOLD (2020), DNA barcode sequences were prepared only for 610 of 10,000 taxa. Also, juvenile instars were described only for $8 \%$ of oribatid mite species (Norton \& Ermilov 2014) and even a lower percentage had their microbiomes, life cycles, ecology and feeding preferences, chemistry of defensive glands or phylogenetic relationships investigated. To summarise, because of the presence of alien invertebrates, palm houses and other greenhouses can be a useful source of knowledge about the still enigmatic taxa from almost all over the world.

\section{ACKNOWLEDGEMENTS}

Authors would like to thank the students of the Student Naturalist Society (Invertebrate Section) of Faculty of Biology, Adam Mickiewicz University, and especially S. Chmielewski, M. Draga, D. Fajfer, A. Łukasiewicz, J. Wysocka and M. Zmudziński for their help in collecting the material for study. The greatest thanks goes to M. Kolicka: for coordination of sampling collection, help in organization of research expedition and in preparing photographs of mites. Authors want to thank the managements of Fata Morgana Greenhouse in Prague, The BerlinDahlem Botanical Garden, Central Botanical Garden of the National Academy of Sciences of Belarus in Minsk and Ecology Center A.S. Pushkin Brest State University (especially Petr Vacík and Aliaksandr Kolbas) for enabling the material collection. Authors are also grateful to Ladislav Miko for help in problematic species' identification and two anonymous reviewers for their very constructive comments on earlier drafts.

\section{REFERENCES}

AOKI J. 1992. Oribatid mites inhabiting orchid plants in a greenhouse. Journal of the Acarological Society of Japan 1. 1: 7-13. BochNiAK N. 2015. Mechowce (Acari, Oribatida) występujące na terenie Palmiarni w Poznaniu [Oribatid mites (Acari, Oribatida) occurring in the Palm House in Poznań]. MSc thesis, Faculty of Biology, Adam Mickiewicz University, Poznań. BoERo F. 2010. The study of species in the era of biodiversity: a tale of stupidity. Diversity 2.1: 115-126.

BOLD 2020. Barcode Of Life Data System. http://www.boldsystems.org/: Accessed January 2020.

DOMES K., SCHEU S. \& MARAUN M. 2007. Resources and sex: soil re-colonization by sexual and parthenogenetic oribatid mites. Pedobiologia 51.1: 1-11.

EASIN 2020. European Commission - Joint Research Centre - European Alien Species Information Network (EASIN) https://easin.jrc.ec.europa.eu/ : Accessed January 2020.

HAMMER M. 1969. Oribatids found at Plant Quarantine Station in the USA. Videnskabelige Meddelelser Dansk Naturhistorisk Forening 752: 63-78. 
Kolicka M., DZIUBA M. K., ZAWIERUCHA K., KUCZYŃSKA-KIPPEN N. \& KoTWICKI L. 2015. Palm house-biodiversity hotspot or risk of invasion? Aquatic invertebrates: The special case of Monogononta (Rotifera) under greenhouse conditions. Biologia 70.1: 94-103.

Kolicka M., Gwiazdowicz D.J., HupaŁo K., JabŁońska A., Kotwicki L., Kornobis F., Lamentowicz M., Magowski W., Marcisz K., Pronin M., Reczuga M. K., Olszanowski Z. \& Zawierucha K. 2016. Hidden invertebrate diversity-phytotelmata in Bromeliaceae from palm houses and florist wholesalers (Poland). Biologia 71. 2: 194-203.

KRANTZ G. W. \& WALTER D. E. (eds). 2009. A manual of acarology. 3rd ed. Texas Tech University Press, Lubbock, TX, USA.

Lehmitz R., Russell D., Hohberg K., Christian A. \& XYlander W. E. 2011. Wind dispersal of oribatid mites as a mode of migration. Pedobiologia, 54(3), 201-207.

Lin K., Wu K., ZHANG Y. \& GUO Y. 2007. Overwintering and population dynamics of Bemisia tabaci biotype B in greenhouse during the spring in northern China. Crop Protection, 26 (12), 1831-1838.

NORTON R. A. 1980. Observations on phoresy by oribatid mites (Acari: Oribatei). International Journal of Acarology, $6(2), 121-130$.

MAgILTION M., MARAUn M., EMMERSON M., \& CARUSO T. 2019. Oribatid mites reveal that competition for resources and trophic structure combine to regulate the assembly of diverse soil animal communities. Ecology and Evolution, 9(14), 8320-8330.

MiKo L. 2016. Oribatid mites (Acarina: Oribatida) of the Czech Republic. Revised check-list with a proposal for Czech oribatid nomenclature. Klapalekiana 52 (Suppl.): 1-302.

NiEdBAŁA W. 2010. Contribution to the knowledge of ptyctimous mites (Acari, Oribatida) in the Palm House in Poznań. Biological Letters 47. 2: 87-92.

NiedBaŁA W. 2014. New data about ptyctimous mites (Acari, Oribatida) in Polish palm houses. Turkish Journal of Zoology 38. 5: 660-664.

NiEDBAŁA W. 2018. Further data on the occurrence of ptyctimous mites (Acari, Oribatida) in European Palm houses. International journal of acarology, 44 (8), 382-385.

NORTON R. A. \& PALMER S. C. 1991. The distribution, mechanisms and evolutionary significance of parthenogenesis in oribatid mites. In: SchuSTER R. \& MURPHY P. W. (eds) The Acari, Reproduction, Development and Life-History Strategies. Chapman \& Hall, London, 107-136.

Norton R. A. \& ERMilov S. G. 2014. Catalogue and historical overview of juvenile instars of oribatid mites (Acari: Oribatida). Zootaxa 3833. 1: 1-132.

SCHÄFFER S., KERSCHBAUMER M., \& KOBLÜLlER S. 2019. Multiple new species: Cryptic diversity in the widespread mite species Cymbaeremaeus cymba (Oribatida, Cymbaeremaeidae). Molecular Phylogenetics and Evolution 135: 185-192.

ScotT-Brown A. S., HodgetTs J., Hall J., Simmonds M. J. S. \& Collins D. W. 2018. Potential role of botanic garden collections in predicting hosts at risk globally from invasive pests: a case study using Scirtothrips dorsalis. Journal of Pest Science 91. 2: 601-611.

Seebens H., Blackburn T.M., Dyer E. E, Genovesi P., Hulme P. E., Jeschke J. M., Pagad S., Pyšek P., Winter M., Arianoutsou M., Bacher S., Blasius B., Brundu G., Capinha C., Celesti-Grapow L., Dawson W., Dullinger S., Fuentes N., JÄGer H., Kartesz J., Kenis M., Kreft H., KÜHn I., LenZNer B., Liebhold A., Mosena A., Moser D., Nishino M., Pearman D., Pergl J., Rabitsch W., Rojas-Sandoval J., Roques A., Rorke S., Rossinelli S., Roy H. E., Scalera R., Schindler S., Štajerová K., TOKARSKA-GuZiK B., VAN KLEUNEN M., WALKER K., Weigelt P., YAMANAKA T. \& ESSL F. 2017. No saturation in the accumulation of alien species worldwide. Nature communications 8: 14435.

SeniczaK S., ItURRondobeitia J. C. \& SeniCZAK A. 2012. The ontogeny of morphological traits in three species of Galumnidae (Acari: Oribatida). International Journal of Acarology 38.7: 612-638.

SENICZAK S., SENICZAK A., KACZMAREK S. \& MARQUARDT T. 2018. Morphological ontogeny of Protoribates dentatus (Acari, Oribatida, Haplozetidae). Systematic and Applied Acarology 23.4: 613-627.

SeXton J. P., MCintyre P. J., Angert A. L. \& RiCE K. J. 2009. Evolution and ecology of species range limits. Annual Review of Ecology, Evolution, and Systematics 40: 415-436.

Skubala P., MleczKo I. \& Niemi R. 2001. Oribatid mite fauna of greenhouses in Upper Silesia, Poland. Fragmenta Faunistica 44. 2: 365-370.

SKUBALA P. \& MARZEC A. 2013. Importance of different types of beech dead wood for soil microarthropod fauna. Polish Journal of Ecology 61: 3: 545-560.

SUBÍAS L. S. 2019. Listado sistemático, sinonímico y biogeográfico de los ácaros oribátidos (acariformes: oribatida) del mundo (Excepto fósiles)(12a actualización). [Systematic, synonymy and biogeographic list of oribatid mites (acariforms: oribatida) of the world (Except fossils) (12th update)]. Graellsia. 60: 3-305. http://escalera.bio.ucm.es/usuarios/bba/cont/docs. Spanish

TEODORESCU I. \& MATEI A. 2010. Native and alien arthropods in several greenhouses (Bucharest area). Romanian Journal of Biology, Zoology 55. 1: 31-42.

WANG C., ZHANG X., PAN X., Li Z. \& ZHU S. 2015. Greenhouses: hotspots in the invasive network for alien species. Biodiversity and conservation, 24 (7): 1825-1829. 
WeIgmann G. 2006. Hornmilben (Oribatida). Die Tierwelt Deutschlands. 76. [Oribatida. Germany's wildlife]. Teil. Goecke \& Evers. Keltern. German.

WILLIAMSON J. \& HARRISON S. 2002. Biotic and abiotic limits to the spread of exotic revegetation species. Ecological applications 12 (1): 40-51.

WissuWA J., SALAMON J. A. \& FRANK T. 2013. Oribatida (Acari) in grassy arable fallows are more affected by soil properties than habitat age and plant species. European Journal of Soil Biology 59: 8-14.

Zangl L., KunZ G., Berg C., \& Koblmüller S. 2019. First records of the parthenogenetic Surinam cockroach Pycnoscelus surinamensis (Insecta: Blattodea: Blaberidae) for Central Europe. Journal of Applied Entomology 143 (3): 308-313.

Zawierucha K., Szymkowiak P., Dabert M. \& Harvey M. S. 2013. First record of the schizomid Stenochrus portoricensis (Schizomida: Hubbardiidae) in Poland, with DNA barcode data. Turkish Journal of Zoology 37. 3 : $357-361$.

\section{STRESZCZENIE}

\section{[Szklarnie - miejskie hotspoty bioróżnorodności obcych gatunków Oribatida]}

Celem badań było sprawdzenie wybranych europejskich szklarni pod kątem obecności obcych gatunków, które mogły zostać sprowadzone przypadkowo wraz z roślinami. Badania zostały przeprowadzone Berlińskim Ogrodzie Botanicznym, Szklarni Fata Morgana w Pradze, Ogrodzie Botanicznym Narodowej Akademii Nauk Białorusi w Mińsku oraz Centrum Ekologii Brzeskiego Uniwersytetu im. Aleksandra Puszkina. W sumie stwierdzono 49 gatunków, z czego aż 23 gatunki obce. Prócz taksonów kosmopolitycznych oraz palearktycznych, obecne były również licznie roztocza Neotropikalne. Uzyskane dane w przyszłości powinny pomóc w badaniach nad trudno dostępnymi gatunkami mechowców, ponieważ umożliwiają ich łatwiejsze pozyskanie oraz wytypowanie taksonów potencjalnie zdolnych do kolonizacji terenów poza szklarniami. 